\title{
Fundoplication versus medical management of gastroesophageal reflux disease: systematic review and meta-analysis
}

\author{
Eva Blozik
}

Received: 25 November 2013 / Accepted: 30 December 2013/Published online: 23 May 2014

(C) Springer Science+Business Media New York 2014

To the Editor,

Thank you very much for notifying us about the letter by Lockwood and Giraldi [1] concerning our article [2]. They identified an error in our article that is embarrassing and unexpected for us, as we had a rigorous quality assurance system for data extraction in place. In the Results section, the GERD-related symptoms subsection should read as follows:

Three studies reported flatulence/bloating to be more frequent after surgical intervention [17, 24, 25], whereas two publications did not find a difference between the study arms [15, 22], and one additional publication reported higher rates for the medical arm [20].

In the Discussion section, the second paragraph should read as follows:

However, the prevalence of dysphagia, flatulence, and bloating tended to increase after fundoplication, and the results for other symptoms associated with the surgical intervention, such as inability to belch or vomit, abdominal fullness, or increased abdominal girth, were inconsistent.

Despite the above-mentioned corrections, the overall message of the article does not need to be changed. We sincerely apology for these accidental errors (Table 1).
Table 1 should read as follows:

\begin{tabular}{|c|c|c|c|c|c|}
\hline Author & Instrument & Symptom & $\begin{array}{l}\text { Follow-up } \\
\text { time } \\
\text { (years) }\end{array}$ & $\begin{array}{l}\text { More } \\
\text { frequent } \\
\text { in }\end{array}$ & $\begin{array}{l}\text { Reported } \\
\text { effect } \\
\text { estimate }\end{array}$ \\
\hline \multirow[t]{3}{*}{$\begin{array}{l}\text { Galmiche } \\
\text { et al. } \\
\text { [25] }\end{array}$} & $\begin{array}{l}\text { Prevalence of } \\
\text { GERD } \\
\text { symptoms }\end{array}$ & Dysphagia & 5 & $\begin{array}{r}\text { Surgical } \\
\text { group }\end{array}$ & $\begin{array}{r}5 \text { vs. } 11 \% \\
p<0.001\end{array}$ \\
\hline & & Bloating & 5 & $\begin{array}{c}\text { Surgical } \\
\text { group }\end{array}$ & $\begin{array}{r}28 \text { vs. } 40 \% \\
p<0.001\end{array}$ \\
\hline & & Flatulence & 5 & $\begin{array}{c}\text { Surgical } \\
\text { group }\end{array}$ & $\begin{array}{r}40 \text { vs. } 57 \% \\
p<0.001\end{array}$ \\
\hline
\end{tabular}

\section{References}

1. Lockwood M, Giraldi E (2014) Commentary on "Rickenbacher et al. Fundoplication versus medical management of gastroesophageal reflux disease: systematic review and meta-analysis." Surg Endosc. doi:10.1007/s00464-013-3140-z. Surg Endosc. doi:10. 1007/s00464-013-3386-5

2. Rickenbacher N, Kötter T, Kochen MM, Scherer M, Blozik E (2014) Fundoplication versus medical management of gastroesophageal reflux disease: systemic review and meta-analysis. Surg Endosc 28:143-155
E. Blozik $(\bowtie)$

Department of Primary Medical Care, University Medical Center Hamburg-Eppendorf, Martinistr. 52, 20246 Hamburg, Germany e-mail: e.blozik@uke.de 